\title{
PREFERRED REASONS IN SELECTING TEACHING PROFESSION AS A LIFE CAREER: A CASE STUDY OF PRE-SERVICE TEACHERS
}

\author{
Nargis Noor \\ Research Scholar, \\ Department of Education, University of Loralai, \\ Balochistan, Pakistan \\ Email: nargisnoor71@gmail.com \\ Huma Akram \\ Research Scholar, \\ Department of Education, Northeast Normal University, \\ Changchun, China \\ Email: akram_huma1@outlook.com
}

\section{Muhammad Kamran}

Assistant Professor,

Department of Education, University of Loralai,

Balochistan, Pakistan

Email: kamrankundi86@gmail.com

\begin{abstract}
Commitment and efficiency of teachers have an important input in the successful accomplishment of educational objectives of any nation; thus, highly motivated teachers are vital for an effective educational approach. By using a quantitative method, this study examined why teachers select the teaching as a profession for their life career. Through the purposive sampling, pre-service teachers from the University of Loralai were chosen in which 147 students participated in this research. Researchers collected the data through questionnaires and analyzed it by using descriptive and inferential statistical tests. The findings point out that majority of preservice teachers choose the teaching profession as their life career due to the altruistic-intrinsic reasons because it received the highest mean as compared to the other reasons (i.e., extrinsic and reasons influenced by others). The extrinsic reasons and reasons influenced by others followed by in order of preference respectively. Regarding the gender variable, male and female pre-service teachers showed significant differences in altruistic-intrinsic reasons. Contrary to this, age, teaching experience and professional qualifications showed no significant differences with the altruistic-intrinsic reasons. Based on the findings, this study suggests that education
\end{abstract}


policy should set standards for teacher education programs to elevate the status of teachers for attracting bright students before and after completing the programs.

\section{KEYWORDS}

Teaching Profession, Career, Pre-service Teachers, Balochistan, Motivational Factors, Quantitative Method.

\section{INTRODUCTION}

Education contributes significantly in raising the productive capacity of a country by helping individuals to realize their abilities and talents (Abotsi et al., 2018). The successful accomplishment of the educational approach relies on highly competent teachers, which can only be expected from motivated teachers. Teachers are considered as those skilled people of a society whose assistance is vital and capable of every profession. Therefore, motivation is considered as an essential element in attracting and retaining of teachers for a successful education system and is viewed as one of the leading areas of attention and aspiration for every student in their schooling (Alberts et al., 2003). It is, therefore, essential to elevate the social and economic standing of the career of teaching by fostering the prevailing conditions of the profession. The motivational factors behind selecting teaching as a career can be extrinsic, intrinsic, and altruistic drivers (Balyer \& Ozcan, 2014). Extrinsic drivers involve all the aspects associated with the external environment, such as earning, position, and working conditions. Intrinsic drivers entail all the aspects intimately associated with ones' enthusiasm and passion for teaching, which ultimately leads to subject knowledge and expertise. Altruistic drivers are related to know the worth and dignity of teaching as a valuable profession and the inclination towards children's development and support to contribute to society. Intrinsic and altruistic grounds are usually common in developed countries, whereas extrinsic reasons are prominent in developing countries (Azman, 2013).

Similarly, Klassen et al. (2011) argue that reasons of aspirations for selecting a teaching profession as a life career are connected with the cultural background of the individual. Altruistic and intrinsic drivers are worthwhile in retaining teachers in that profession. However, on the other hand, individuals may also leave the teaching profession if their expectations and perceptions do not meet in reality. In other words, they may feel disappointed and dissatisfied due to several practical challenges they encounter, such as high workload and inappropriate support in their early career of teaching (Kim \& Cho, 2014). Thus, motivation, consistency, dedication and identification of the desired work are fundamental to sustain in a profession (Krecic \& Grmek, 2005). On the other hand, individuals with extrinsic drivers may undergo dropping out of the situation upon unfulfilling their requirements and desires (Malmberg, 2006). As a result, researchers argue that individuals' aspiration can be 
determined as a blend of all three drivers, which can help to retain both pre-service and in-service teachers within the teaching profession (Sinclair, 2008). Thereby the aspiration of teachers towards the teaching profession plays a significant role in enhancing their capabilities and competencies (Löfström et al., 2010). Beyond that, a harmonious blend among all motivators is suggested to maintain the pace of pedagogical practices of teachers (Struyven et al., 2013).

Moreover, teachers' shortage has been reported as a major problem all over the world. Despite completing teacher education programs, they either leave shortly afterwards or not select the teaching profession (Thomson et al., 2012). The reasons may be the lack of integration of theory into practice since pre-service teachers had terrible experiences regarding Placements of Professional Orientation Programs (Reyneke \& Botha, 2020). In addition, various countries such as the U.K., Australia, Norway, Germany, and other European countries have pointed out the problem of recruitment and retaining of teachers (Watt et al., 2012; Richardson \& Watt, 2010). Similarly, Pakistan is also confronting with the problems of shortage of teachers due to the unavailability of qualified teachers (Akram, 2020), low salary packages (Nasreen \& Afzal, 2020), inadequate teacher training (Akram et al., 2020) and the reputation of the organization (Butt et al., 2020). Pakistan education policy has also addressed the problem of shortage and incompetent teachers, which slows down the quality of education. In order to resolve this issue, it is suggested to raise the social and economic status of teachers in order to motivate others to enter this profession (Pakistan Ministry of Education, 2009). However, the role of government in uplifting the social and economic status of teachers in the eyes of the public is still vague (Mughal \& Siddiqui, 2017). Besides limited work has been conducted (as per researchers' knowledge) to investigate the motivational factors and order of preference that attract individuals to enter this profession. Therefore, this study was conducted focusing on pre-service teachers' reasons for motivation towards choosing the teaching profession.

\section{LITERATURE REVIEW}

\section{Teaching Profession}

From the beginning of time, education is considered as the foundation of a society. Furthermore, teachers are regarded as the key component in the acquisition of an effective educational approach. The teaching profession is a collection of particular fields like teaching skills, didactics, learning and many other personal characteristics required for the profession. The teaching profession makes a relationship between the required knowledge of the specific subject, pedagogical methods and suitable individuality and facts for the individual who selects the teaching profession. Teachers should be highly motivated to retain longer and committed to students (Richardson \& Watt, 2016). Teachers give a lecture and control the class by having the skills of planning and carrying out the lesson, defining the order in the class and ensure the 
students to participate in the class lecture for their concept clarification and easy learning. These skills will be promoted in the teachers through vocational courses and practice, including teacher education programs (Hotaman, 2010).

\section{Choosing Teaching as a Life Career}

Choosing a profession is an important decision, as one cannot switch to another profession easily. When a person is satisfied with his achievements, he/ she will see a successful career in his/ her life. Therefore, a prudent decision is essential regarding the selection of a well-desired career. However, sometimes, external factors also influence and become impediments for selecting a career (Mukminin et al., 2017). Furthermore, the completion of teacher education programs does not provide assurance that successful student-teachers are going to choose teaching as a profession. In contrast, easily attrition from teaching may not necessarily influence the reasons for motivation to choose the teaching profession as a life career (Abotsi et al., 2019). In reference to pre-service teachers' plan and motives, Richardson \& Watt (2016) classified them into three groups: the highly committed sustainers, the highlycommitted shifters, and the lower-engaged renouncers. Regarding motivational reasons in choosing the teaching profession as a working career may also show a discrepancy from one person to another, and Moran et al. (2001) proposed three different motivational factors: (a) intrinsic factors, (b) extrinsic factors, (c) and altruistic factors.

\section{Theoretical Framework}

Since surroundings play a major role in an individual's life, and one cannot stay away from the effect of his/her environment (Lin, 2012), also quoted by Akram et al. (2020). Similarly, Bandura (1977) specified the connection of individuals with their environmental conditions through his social learning theory (SLT) which determined the factors that contribute significantly in an individual's decisions to choose or to stay or leave the teaching profession. On the basis of social learning theory, Bandura (1977), Krumboltz (1979), Mitchell and Krumboltz (1996) linked this theory with the career decision of the individuals. The current study is based on this theoretical framework. Accordingly, the interaction between several factors take part in taking individual's career decisions, such as genetic factors, learning opportunities in teacher education programs, environmental or external influences, aptitude and intellectual patterns, and efficiency (Krumboltz, 1979; Mitchell \& Krumboltz, 1996). These variables may influence the decisions of teachers to stay or leave the teaching profession. Several researchers have followed this theory to develop specific models to elaborate on teachers' reasons for the motivation of selecting teaching as a career (Chapman, 1983; Rots et al., 2010; Rots, Aelterman \& Devos, 2014; Ray et al., 2019). Based on the previous studies regarding the application of social learning theory, the 
current study adopts the following predictive variables that demonstrate the pre-service teachers' reasons for choosing teaching as a life career.

\section{(a) Intrinsic motivational factors}

The intrinsic motivation can be regarded like an internal satisfaction responsible for attracting an individual toward a specific profession wishing to improve. If they choose to teach, the pleasure of teaching keeps them retain in the teaching profession (Gagne $\&$ Deci, 2005). If a teacher is satisfied in his profession or if he is competent in teaching a particular subject, it means that he is motivated intrinsically and can pursue his profession in an excellent manner (Reeve, 2009). Moreover, if someone has intrinsic reasons, he cannot be subdued by adverse circumstances.

\section{(b) Extrinsic motivational factors}

These motivational factors are concerned with the economic and other external incentives such as spending time with family, employment security and social status. The more the teachers gain the incentives, the higher degree they are supposed to sustain in that profession (Watt et al., 2012). When a teacher has a direct linkage with the job security, reasonable workload and comforts for choosing the teaching profession, he is employed with extrinsic reasons. Thus, extrinsic motivational factors can be used to attract more professional and talented teachers for the teaching purposes.

\section{(c) Altruistic motivational factors}

Altruistic motivational factors are concerned with encouraging teachers without any visible beneficial supply from the job of teaching (Moran et al., 2001). A teacher helps students regardless of any personal advantage, and these altruistic reasons contribute for the progress and prosperity of the society (Khajavy et al., 2017).

\section{(d) Influence by Others Reasons}

Teachers adopt teaching career not because of their personal grounds but on account of other external factors that compel individuals to adopt teaching as a profession (Cermik et al., 2010). The motivational level of students is also influenced by their personal school experiences and the work with teachers (Low et al., 2017).

Different research results state that people select a profession because of different results. According to Akpochafo (2020), females prefer intrinsic reasons; however, males are inclined towards extrinsic reasons for motivation for selecting teaching as a profession. Besides, females select the teaching profession as a career because of practical reasons (Korb, 2010). Furthermore, extrinsic reasons such as job guarantee, salary, and social status also encourage teachers to enter the teaching profession and retain it (Kim, \& Kim, 2015). Moreover, Stichert (2005) state that altruistic reasons are essential for potential teachers and first-year teachers. 
Considering all the facts, it is apparent that student-teachers select the teaching profession because of their various motivational factors. Therefore, the current study endeavours to investigate the preferences of motivational factors that influence preservice teachers' intention to select this profession along with the differences of several demographic features.

\section{RESEARCH OBJECTIVES}

This study had the following objectives:

1. To investigate the reasons that preferred by pre-service teachers for the selection of the teaching profession as a life career.

2. To examine the statistical differences in pre-service teachers' highest preferred reasons regarding their demographic variables such as gender, teaching experience, and professional qualification.

\section{RESEARCH HYPOTHESES}

1. There is a significant difference between pre-service teachers' highest preferred reasons with respect to their gender.

2. There is a significant difference between pre-service teachers' highest preferred reasons with respect to their teaching experience.

3. There is a significant difference between pre-service teachers' highest preferred reasons with respect to their professional qualification.

\section{RESEARCH METHODOLOGY}

The current study utilized a quantitative research design as it was the most suitable framework for investigating preferred motivational reasons via numerical representation (Watson, 2015).

\section{Sampling Technique}

Since the pre-service teachers are associated with the Department of Education in the University of Loralai, Balochistan, Pakistan, therefore, respondents of the study were selected from the Department of Education as a target population. The sampling procedure was followed through a purposive sampling method, as this technique allows a researcher to choose a particular range of respondents (Tongco, 2007). In this respect, Questionnaires (as data collection tool) were distributed among 150 preservice teachers purposively, but 147 completed the whole questionnaires. Their demographic features are represented below in table 1.

Table 1. Demographic features

\begin{tabular}{lll}
\hline Groups & $\mathrm{N}$ & $\%$ \\
\hline Gender & & \\
\hline
\end{tabular}




\begin{tabular}{lll}
\hline Male & 107 & 72.7 \\
Female & 40 & 27.2 \\
\hline Teaching experience & \\
\hline $1-5$ & 109 & 74.1 \\
$6-10$ & 18 & 12.2 \\
$11-15$ & 15 & 10.2 \\
$16-$ above & 5 & 3.4 \\
\hline Professional Qualification & & \\
\hline CT & 07 & 4.7 \\
ADE & 17 & 11.5 \\
B.Ed & 82 & 55.7 \\
M.Ed & 41 & 27.8 \\
\hline
\end{tabular}

\section{Survey Instrument}

The data were collected from the pre-service teachers by a closed-ended questionnaire named as "Choosing Teaching Profession as a Career Scale (CTPCS)", which was formulated by Lai et al. (2005). The said questionnaire was published and was used intensively by other researchers (e.g., Balyer \& Özcan, 2014; Mukminin et al., 2017). The items in this questionnaire were grouped into three categories which were named as altruistic-intrinsic factors (9 items), extrinsic factors ( 8 items) and influenced by others ( 5 items). The responses of all the items of each category were constructed on a five-point Likert scale ranging from "Strongly Disagree" to "Strongly Agree".

\section{Pilot Study and Reliability of the Instrument}

Face validity of the questionnaire was reviewed by an expert from the said university's English department, whose name was kept confidential. After this, the pilot study was conducted among 20 pre-service teachers, paving the way for the questionnaire's reliability. The Cronbach Alpha Reliability Coefficient was calculated through the SPSS Version 20, separately for each category of the questionnaire shown in table 2 below. Altruistic-Intrinsic reasons had 0.7, extrinsic reasons had 0.7, and reasons influenced by others had 0.9 Cronbach Alpha Reliability Coefficients which were strong enough to carry the actual study.

Table 2. Reliability of the Questionnaire

\begin{tabular}{llll}
\hline Categories & Alpha Value & $\begin{array}{l}\text { Standardized } \\
\text { Alpha Value }\end{array}$ & No of Items \\
\hline Altruistic-Intrinsic reasons & .708 & .713 & 9 \\
Extrinsic reasons & .708 & .751 & 8 \\
Influence by others & .933 & .935 & 5 \\
\hline
\end{tabular}




\section{Data Analysis}

All the collected data were analyzed by employing various descriptive and inferential statistical tests, i.e., mean, standard deviation, t-test, and ANOVA.

\section{RESULTS}

\section{Research Objective 1}

In order to find out the rank of preferred motivational reasons, descriptive statistical tests, i.e., Mean, Median and Standard Deviation, were applied. Table 3 below shows that altruistic-intrinsic reasons got the highest rank, demonstrating that the pre-service teachers were highly motivated by the altruistic-intrinsic reasons to select the teaching profession as a career. The other two reasons, i.e., extrinsic reasons and reasons influenced by others, secured the rank of second and third position, respectively.

Table 3. Preferred reasons for pre-service teachers

\begin{tabular}{llll}
\hline S. No & Preferred Reasons & Mean & S.D \\
\hline $\mathbf{1}$ & Altruistic-Intrinsic Reasons & 4.11 & 1.12 \\
$\mathbf{2}$ & Extrinsic Reasons & 3.81 & 0.93 \\
$\mathbf{3}$ & Reasons Influenced by others & 3.73 & 1.50 \\
\hline
\end{tabular}

\section{Research Objective 2 (Hypotheses)}

To test the hypotheses of this study, inferential statistics, i.e., t-test and ANOVA test were performed. t-test was explicitly applied to test the hypothesis regarding gender, while ANOVA tests were applied to test the hypotheses regarding teaching experience and professional qualification.

\section{Hypothesis 1}

Table 4 below shows the significant difference between genders $(t=-1.31 ; p=.003)$ at alpha level .05. Furthermore, female pre-service teachers got a higher mean score of 4.38 than males (mean score: 4.26 ), which shows that female pre-service teachers were more inclined towards the teaching profession than males due to altruistic-intrinsic reasons; therefore, hypothesis 1 regarding gender is accepted.

Table 4.t-test in terms of gender regarding altruistic-intrinsic reasons

\begin{tabular}{lllllll}
\hline $\begin{array}{l}\text { Altruistic-intrinsic } \\
\text { reasons }\end{array}$ & $\mathbf{N}$ & Mean & SD & df & t & Sig \\
\hline Male & 107 & 4.2606 & .53 & 145 & -1.31 & .003 \\
Female & 40 & 4.3806 & .36 & & & \\
\hline
\end{tabular}

\section{Hypothesis 2}

Table 5 demonstrates no significant differences regarding pre-service teachers' 
altruistic-intrinsic reasons and teaching experience variable $(F=.475 ; p=.70)$ at alpha level .05. Thus, it shows that pre-service teachers' teaching experience produced no significant differences against altruistic-intrinsic reasons. Therefore, hypothesis 2 regarding teaching experience is rejected.

Table 5. ANOVA for teaching experience against altruistic-intrinsic reasons

\begin{tabular}{llll}
\hline $\begin{array}{l}\text { Teaching } \\
\text { experience }\end{array}$ & $\mathbf{N}$ & $\mathbf{F}$ & Sig \\
\hline $1-5$ & 109 & .475 & .701 \\
$6-10$ & 18 & & \\
$11-15$ & 15 & & \\
$16-$ above & 05 & & \\
\hline
\end{tabular}

\section{Hypothesis 3}

Table 6 illustrates no significant differences regarding pre-service teachers' altruisticintrinsic reasons and professional qualification variable $(F=.526 ; p=.756)$ at alpha level .05 . Thus, pre-service teachers' professional qualification produced no significant differences against altruistic-intrinsic reasons. Therefore, hypothesis 3 regarding professional qualification is rejected.

Table 6. ANOVA for professional qualification against altruistic-intrinsic reasons

\begin{tabular}{llcc}
\hline $\begin{array}{l}\text { Professional } \\
\text { Qualification }\end{array}$ & N & F & Sig \\
\hline CT & 07 & .526 & .756 \\
ADE & 17 & & \\
B.Ed. & 82 & & \\
M.Ed. & 41 & & \\
\hline
\end{tabular}

\section{DISCUSSION}

This quantitative case study was conducted to investigate the preferred motivational reasons that stimulate pre-service teachers to select the teaching profession as a life career. In the context of University of Loralai, the respondents were asked to tell their motivational reasons to teach. The results of the study propose that teachers are mostly encouraged by altruistic-intrinsic reasons to enter teaching with a desire of participating in social reforms by educating society. This finding shows consistency with the findings of Mukminin et al. (2017); Drahmann et al. (2019); Bruinsma and Canrinus (2012). Furthermore, this study also indicated that male and female preservice teachers possess a significant difference when it comes to altruistic-intrinsic reasons. The female pre-service teachers showed a greater tendency than males to join the teaching profession as a life career. This finding shows consistency with the findings of Sharif et al. (2014) and Maliki (2013). It indicates that female teachers 
fulfill their duties with dedication, responsibility and zeal. It has also been indicated in the studies that commitment plays a vital role in pre-service teachers' intention to select the teaching profession as a life career (Rots et al., 2010), which further results in job satisfaction and retention (Tait, 2008).

Teachers with sufficient instructional experience are supposed to focus broadly and show a higher degree of sustainability in the teaching profession and make it a life career (Feiman-Nemser, 2001). Regarding teaching experience, the study did not find any significant difference; this finding shows contradiction with the finding of Sharif et al. (2016); accordingly, teaching and learning experiences contribute significantly in retaining teachers in the teaching profession.

Similarly, regarding professional qualification, the study did not find any significant difference, this finding shows inconsistency with the findings of Rots et al. (2014); accordingly, academic and teacher education program play a significant role in motivating graduates to enter into the teaching profession. In sum, the results and the implications of the current study are useful to be employed for future research by policymakers, the school system, national or international researchers, and on society.

\section{CONCLUSION}

In conformity with the findings, this study specifically showed that pre-service teachers select the teaching profession as a life career on account of altruistic-intrinsic reasons. Thus, underlying the altruistic-intrinsic reasons, it is evident that female preservice teachers are more likely to join the teaching profession than males. This finding highlights the fact that the teaching profession is a feminine profession as it has become a trend in developed countries such as Australia, Brazil, Canada and the United Kingdom and some developing countries (Kelleher, 2011). Therefore, this study draws attention to the factors that make teaching more feminine than masculine. It implies to investigate the factors that dissatisfy males from choosing the teaching profession as a life career and suggests solutions to enhance their motivation. In order to explore more, a qualitative study should be conducted to investigate teachers' reason to select the career of teaching and figure out ways to attract bright students to the teaching profession.

\section{RECOMMENDATIONS}

This study provides an expedient insight into the time when the education system around the world is being experienced with the problems of low recruitment and retention of the teachers and thereby suggests ways to how to improve the effectiveness of teaching. In line with the findings, the current study recommends that teachers mostly follow their personal and social usefulness values instead of extrinsic values. It is, therefore, suggested that teachers should be given adequate opportunities to enjoy 
employment security, spending time with their families and social balance, which are vital in meeting the needs of personal and social usefulness values. Furthermore, due to several limitations, this study was only conducted at the University of Loralai. To broaden the understanding, another study should be conducted investigating perceptions of teachers at the national level.

\section{REFERENCES}

Abotsi, A. K., Dsane, C. F., Babah, P. A., \& Kwarteng, P. (2019). Factors influencing the choice of teaching as a career: An empirical study of students in colleges of education in Ghana. $\begin{array}{llll}\text { Contemporary Social } & \text { Science, }\end{array}$ https://doi.org/10.1080/21582041.2019.1675092

Abotsi, A. K., Yaganumah, N., \& Obeng, H. E. (2018). Dropout's issues and its economic implications; evidence from rural communities in Ghana. Journal_of Economics and Economic Education Research, 19(1), 1-13.

Akpochafo, G. O. (2020). Motivation for Preservice Students to Choose a Teaching Career by Gender, Age, and Subject Area in Nigeria. International Journal of Education and Practice, 8(2), 289-297.

Akram, H., (2020). Education Governance in Pakistan: a Critical Analysis of Challenges. Journal of Social Sciences Advancement, 1(01), 38-41.

Akram, H., Kamran, M., \& Ahmad, N. (2020). An Examination of the Encountered Challenges of Pakistani International Students in China: A Case Study of First-Year Students. Pakistan Journal of Social Sciences, 40(4), 1567-1576.

Alberts, C., Mbalo, N. F., \& Ackermann, C. J. (2003). Adolescents' perceptions of the relevance of domains of identity formation: A South African cross-cultural study. Journal Youth and Adolescence, 32(3), 169-184. http://dx.doi.org/10.1023/A:1022591302909

Azman, N. (2013). Choosing Teaching as a Career: Perspectives of Male and Female Malaysian Student Teachers in Training. European Journal of Teacher Education, 36(1), 113-130. http://dx.doi.org/10.1080/0261976 8.2012.678483

Balyer, A., \& Özcan, K. (2014). Choosing Teaching Profession as a Career: Students' Reasons. International Education Studies, 7(5), 104-115.

Bandura, A. (1977). Social learning theory. Englewood Cliffs, NJ: Prentice Hall.

Bruinsma, M. F., \& Canrinus, E. T. (2012). The factors influencing teaching (FIT)-choice scale in a Dutch teacher education program. Asian-Pacific Journal of Teacher Education, 40(3), 249-269.

Butt, A., Lodhi, R. N., \& Shahzad, M. K. (2020). Staff retention: a factor of sustainable competitive advantage in the higher education sector of Pakistan. Studies in Higher Education, 45(8), 1584-1604. http://dx.doi.org/10.1080/03075079.2019.1711038

Chapman, D. W. (1983). A Model of the Influences on Teacher Retention. Journal of Teacher Education 34, 43-49.

Drahmann, M., Merk, S., Cramer, C., \& Rothland, M. (2019). Pre-service teachers in Germany's pluralistic scholarship system and their motivations for becoming teachers. 
European Journal of Teacher Education, 42(2), 135-150.

Feiman-Nemser, S. (2001). From Preparation to Practice: Designing a Continuum to Strengthen and Sustain Teaching. Teachers College Record, 103(6), 1013-1055. doi:10.1111/01614681.00141.

Gagne, M., \& Deci, E. L. (2005). Self-determination theory and work motivation. Journal of Organizational Behavior, 26, 331-362. http://dx.doi.org/10.1002/job.322

Hotaman, D. (2010). The teaching profession: Knowledge of subject matter, teaching skills and personality traits. Procedia-Social and Behavioral Sciences, 2, 1416-1420.

Kelleher, F. (2011). Women and the teaching profession: Exploring the feminization debate. London: Commonwealth Secretariat and UNESCO.

Khajavy, G. H., Ghonsooly, B. \& Fatemi, A. H. (2017). Testing a Burnout Model Based on Affective-motivational Factors among EFL Teachers. Current Psychology, 36, 339349. https://doi.org/10.1007/s12144-016-9423-5

Kim, H., \& Y. J. Cho. (2014). Pre-service Teachers' Motivation, Sense of Teaching Efficacy, and Expectation of Reality Shock. Asia-Pacific Journal of Teacher Education, 42(1), 67-81. https://doi.org/10.1080/1 359866X.2013.855999

Kim, T. Y., \& Kim, Y. K. (2015). Initial career motives and demotivation in teaching English as foreign language: Cases of Korean EFL teachers. Porta Linguarium, 24, 77-92.

Klassen, R. M., Al-Dhafri, S., Hannok, W., \& Betts. S. M. (2011). Investigating Pre-Service Teacher Motivation across Cultures Using the Teachers' Ten Statements Test. Teaching and Teacher Education, 27(3), 579-588.

Korb, K. (2010). Do students in the faculty of education choose teaching as a last resort career? Implications for teacher preparation programs. International Journal of Educational Studies, 1, 117-121.

Krecic, M., \& Grmek, M. (2005). The reasons students choose teaching professions. Educational Studies, 31, 265-274.

Krumboltz, J. D. (1979). A Social Learning Theory of Career Choice. In Social Learning Theory and Career Decision Making, edited by M. Mitchell, G. B. Jones and J. D. Krumboltz, 19-49. Cranston, RI: Carroll Press.

Lai, K., Chan, K., Ko, K., \& So, K. (2005). Teaching as a career: a perspective from Hong Kong senior secondary students. Journal of Education for Teaching, 31(3), 153-168. https://doi.org/10.1080/02607470500168974

Lin, M. (2012). Students of Different Minds: Bridging the Gaps of International Students Studying in the U.S. US-China Education Review, 2(3), 333-344.

Löfström, E., Poom-Valickis, K., Hannula, M. S. \& Mathews. S. R. (2010). Supporting Emerging Teacher Identities: Can We Identify Teacher Potential among Students? European Journal of Teacher Education, 33(2), 167-184.

Low, E., Ng, P., Hui, C., \& Cai, L. (2017). Teaching as a career choice: Triggers and drivers. Australian Journal of Teacher Education, 42(2), 28-46.

Maliki, A. E. (2013). Attitudes towards the teaching profession of students from the faculty of education, Niger Delta University. International Journal of Social Science Research, 1(1), 11-18.

Mitchell, L. K., \& J. D. Krumboltz. (1996). Krumboltz's Theory of Career Choice and Counseling. In Career Choice and Development, edited by D. Brown and L. Brooks, 233-280. San Francisco: Jossey-Bass. 
Malmberg, L. E. (2006). Goal-orientation and Teacher Motivation among Teacher Applicants and Student Teachers. Teaching and Teacher Education, 22(1), 58-76. https://doi.org/10.1016/j.tate.2005.07.005

Moran, A., Kilpatrick, R., Abbott, L., Dallat, J. \& McClune, B. (2001). Training to teach: Motivating factors and implications for recruitment. Evaluation and Research in Education, 15,17-32.

Mughal, T. I., \& Siddiqui, M. R. (2017). Exploring the Relationship between Teachers' Socioeconomic Status and Their Teaching Profession Attitude at Secondary School Level. Pakistan Journal of Education, 34(1), 95-112.

Mukminin, A., Kamil, D., Muazza, M., \& Haryanto, E. (2017). Why teacher education? Documenting undocumented female student teachers' motives in Indonesia: A case study. The Qualitative Report, 22(1), 309-326.

Nasreen, K., \& Afzal, M. T. (2020). Strengths, weaknesses, opportunities and threats in higher education: a SWOT analysis of Allama Iqbal Open University Islamabad (Pakistan). Asian Association of Open Universities Journal, 15(3), 321-333.

Pakistan Ministry of Education (MoE). (2009). National education policy 2009. Islamabad: Government of Pakistan.

Ray, A., Dhir, A., Bala, P.K., \& Kaur, P. (2019). Why do people use food delivery apps (FDA)? A uses and gratification theory perspective. Journal of Retailing and Consumer Services, 51, 221-230.

Reyneke, M. \& Botha, C. (2020). The professional orientation of first year student teachers in a non-placement work-integrated learning program. International Journal of WorkIntegrated Learning, 21(3), 303-16.

Reeve, J. (2009). Why teachers adopt a controlling motivating style toward students and how they can become more autonomy supportive. Educational Psychologist, 44, 159-175.

Richardson, P. W. \& Watt, H. M. G. (2016). Factors influencing teaching choice: Why do future teachers choose the career? In J. Loughran \& M. L. Hamilton (Eds.), International Handbook of Teacher Education, Vol. 2 (Part IV), 275-304. Singapore: Springer. https://doi.org/10.1007/978-981-10-0369-1_8

Richardson, P. W., \& Watt, H. M. G. (2010). Current and future directions in teacher motivation research. In T. C. Urdan \& S. A. Karabenick (Eds.), The decade ahead: Applications and contexts of motivation and achievement, 139-173. Emerald: Bingley.

Rots, I., Aelterman, A., \& Devos, G. (2014). Teacher education graduates' choice (not) to enter the teaching profession: does teacher education matter? European Journal of Teacher Education, 37(3), 279-294. https://doi.org/10.1080/02619768.2013.845164

Rots, I., Aelterman, A., Devos, G., \& Vlerick, P. (2010). Teacher education and the choice to enter the teaching profession: A prospective Study. Teaching and Teacher Education, 26, 1619-1629.

Sharif, T, Hossan, C. G, \& McMinn, M. (2014). Motivation and Determination of Intention to Become Teacher: A Case of B.Ed. Students in UAE, International Journal of Business and Management, 9(5), 60-73.

Sharif, T, Upadhyay, D., \& Ahmed, E. (2016). Motivational factors influencing teaching (FIT) as a career: an empirical study of the expatriate teachers in the emirates. The Journal of Developing Areas, 50(6), 209-225.

Sinclair, C. (2008). Initial and Changing Student Teacher Motivation and Commitment to 
Teaching. Asia Pacific Journal of Teacher Education, 36(2), 79-104. https://doi.org/10.1080/13598660801971658

Stichert, E. G. (2005). Pre-service science teachers' perception of profession with metaphorical images and reasons of choosing teaching as a profession. Unpublished master's thesis. Ankara: Middle East Technical University School of Natural and Applied Sciences.

Struyven, K., K. Jacobs, \& F. Dochy. (2013). Why Do They Want to Teach? The Multiple Reasons of Different Groups of Students for Undertaking Teacher Education. European Journal of Psychology of Education, 28(3), 1007-1022. https://doi.org/10.1007/s10212-012-0151-4

Tait, M. (2008). Resilience as a contributor to novice teacher success, commitment, and retention. Teacher Education Quarterly, 35, 57-75.

Thomson, M. M., Turner, J. E., \& Nietfeld, J. L. (2012). A typological approach to investigate the teaching career decision: Motivations and beliefs about teaching of prospective teacher candidates. Teaching and Teacher Education, 28, 479-499.

Tongco, M. D. C. (2007). Purposive sampling as a tool for informant selection. Ethnobotany Research \& Applications, 5, 147-158.

Watson, R. (2015). Quantitative research. Nursing Standard, 29(31), 44-48 https://doi.org/10.7748/ns.29.31.44.e8681

Watt, H. M. G., Richardson, P. W., Klusmann, U., Kunter, M., Beyer, B., Trautwein, U., \& Baumert, J. (2012). Motivations for Choosing Teaching as a Career: An International Comparison Using the FIT-choice Scale. Teaching and Teacher Education 28(6), 791805. https://doi.org/10.1016/j.tate.2012.03.003 